\title{
Juridical Review on Process Loading Liability Rights to Land That Has Not Registered In the District Of Semarang
}

\author{
Ika Yulia Ningrum ${ }^{1}$, Anggrin Gayuh Praptiwi ${ }^{2}$ and Setyawati
}

Abstract. This study aims to analyze the process of Encumbrances On land that has not been registered in the District of Semarang, Barriers which appeared in the Proceedings Encumbrances On Land Not Yet Enrolled in the District of Semarang and solutions to overcome barriers Appears In The Process Encumbrances On Land Not Yet registered in the District of Semarang.

This study uses empirical juridical approach, the approach to reviewing the legislation relating to the issues to be discussed, and also conducted a field approach to obtain information as supporting material. Specifications of this research is descriptive analysis that describes the laws that apply associated with legal theories and practice of positive law concerning these issues.

Based on the research results that the implementation of Encumbrances against certified land not yet in practice never done by the bank by making APHT directly against it and still haven't yet certified the lands. Bank in this case was limited to making SKMHT only. Obstacles that arise in the process of loading encumbrance on land that has not been registered in the District of Semarang is when the giver of mortgage has died, a typing error and the installation of the second rank security rights. The solution is under hand sales, writing and checking certificates rectification katas ha of new land.

Keywords: Land Registry; Loading Liability Rights, Land That Has Not Registered

\section{Introduction}

In Article 1 paragraph 1 of Act 4 of 1996 on Mortgage, hereinafter referred to UUHT mentioned that Encumbrance Land Along related with Objects Land hereinafter called Mortgage is fiduciary right imposed on Land Rights referred to in the Act No. 5 of 1960 on Basic Regulation of Land, hereinafter referred to BAL, following or not following other objects that are one (1) the unity of the country, for the repayment of debt of certain give Positions precedence to creditors of certain of the Creditors.

UUHT provides an opportunity for owners of Land that has not been certified for the ground's Rights Pledge Encumbrance. It is mentioned in Article 10 paragraph (2) UUHT which states that if the Object Encumbrance form Land Rights derived from the Conversion Rights of the old, Eligible for registration but Registration is not done, Giving Mortgage done simultaneously with the requested Right Registration the land in question. Although the legislation is possible imposition of Encumbrance of the land that has not been certified, but generally Own Land Rights that have not been certified experiencing difficulties because most creditors want the land that has been certified because there is strong evidence of Ownership Rights to Land. It thus makes an obstacle for owners of Land that has not been certified, if you want to obtain funds from other parties, ie creditors. Nevertheless, against lands that have not been certified may also be charged Encumbrance throughout the administration is carried out in conjunction with the Application for Registration of Rights to Land concerned.

Problems of Mortgage Encumbrances on land that has not been certified to be

\footnotetext{
${ }^{1}$ Students of Master of Notarial Law, Faculty Of Law, Universitas Islam Sultan Agung / Staff at the Notary / PPAT office, Regina Hastari Sumarno, SH, MKn email ikayulian28@gmail.com

2 Students of Master of Law, Faculty Of Law, Universitas Islam Sultan Agung email anggring@gmail.com
} 
increasingly complicated as happened in District of Semarang, when Land Rights Holders who have charged Encumbrance died and had Eligible Heirs who inherit. And then Heirs filed a Registration Application for First Land (1) on behalf of All the beneficiary. The things mentioned above according to the authors of interest to be assessed further in at the time of Mortgage, land is not yet have a certificate of Land, it certainly needs to be addressed by the creditor because of the activities distributed Credit Containing Risks that may affect the Health and Business Continuity Bank. ${ }^{3}$ This becomes even more significant when the administration of Encumbrance is given by Power of Attorney Imposing Loading Liability Rights (hereinafter referred SKMHT), due to land not yet registered then Granting SKMHT should be continued with the Deed of Encumbrances (hereinafter referred APHT), not later period 3 (three) months after the SKMHT.

The purpose of this research is to know How Imposition Process Mortgage on land that has not been registered in the District of Semarang; obstacle that comes in the Imposition Process Mortgage on land that has not been registered in the District of Semarang; and Overcome Obstacles Solution that comes in Process Mortgage Encumbrances on Land Not Registered in District of Semarang

\section{Research methods}

The method used in this research is juridical empirical method, in the sense that reviewing the legislation relating to the issues to be discussed, and also conducted a field approach to obtain information as supporting material.

Secondary data used in this study with a literature study data collection methods, namely studying a number of existing literature, especially the set of legislation in the field of Process Mortgage Encumbrances on land that has not been registered in the District of Semarang.

Analysis of data using qualitative descriptive analysis method namely research to describe and interpret an object in accordance with the fact that there is, without exaggeration disclose or describe the data as it is, so that disclose or describe Reality of the phenomenon exists.

\section{Results And Discussion}

\subsection{Process to Loading Liability Rights On land that has not been Registered in District of Semarang}

Mortgage loading process is carried out through two (2) Phase activities, namely Phase Granting Mortgage, which made front of the Land Deed Official (PPAT) and the second phase Mortgage Registration, which is done at the Land Office. Giving Phase Begins Mortgage or Preceded by Promise to Provide Mortgage For Debt Settlement Guarantee particular. Promise to Deliver the Mortgage Poured in and form an integral part of the Relevant Debt Agreement or other agreements which give rise to the debt. This stage can be inferred from the provisions of Article 10 paragraph (1) UUHT which states:

"Granting Mortgage Preceded by Promise to Provide Mortgage Debt As Collateral Redemption particular, who poured in and an integral part of the Relevant Debt Agreement or other agreements which give rise to the debt."

\footnotetext{
${ }^{3}$ Bank Indonesia Semarang, 2018, Penanganan Kredit Bermasalah, Bank Indonesia, Semarang, p 2.
} 
In other words, before the Deed Granting Mortgage Debt is made in the Agreement to include "Promise" Granting Mortgage Debt Repayment as guarantee certain properties Due Encumbrance as Accessoir Agreement. According to the explanation of Article 10 paragraph (1) UUHT, thereby granting the Mortgage shall constitute the Agreement Stirs Legal Relationship Guaranteed Debt Payments are. Based on interview with a notary/PPAT in District of Semarang, Nicky Santika, the implementation of the provisions of Article 10 UUHT mentioned in Practice Banking can be seen from the Contents Credit Agreement as the Treaty of Principal which always included Clause On Collateral, one Point Important set out in this clause is to Ensure Repayment Borrower to Bank properly, either Loan Principal, Interest, Fines and fees and other costs, the debtor submit collateral in the form of land and buildings, plant and results of work done on it which is a unity with the Land and is owned Rightsholders land, and upon Delivery will be made of Power of Attorney Imposing Mortgage or Encumbrance.

Based on interview with a notary / PPAT in District of Semarang, Nicky Santika, promise to give Encumbrance is important to be noticed by the Debtor to remember than words "In and is a part" of the Treaty Anyway, as referred to in Article 10 paragraph (1) UUHT, can be known is not possible Granting Mortgage promise made in a deed that is Separated, even though use of the Power of Attorney Imposing Mortgage (SKMHT). So the "Promise" Granting the Mortgage, previously had Poured first in Debt Agreement, as the Principal Agreement. In other words Giving Mortgage Deed must be based To the previous agreement Promising Debt will do Granting Mortgage. Based on interview with a notary / PPAT in District of Semarang, Nicky Santika, if the creditor Inattentive to foretell Guarantee Agreement Mortgage Debt receivable, then later he was not authorized to Demanding Special Guarantee Mortgage Granting them. While the Mortgage Voluntary Giving by the Borrower or any Third Party always Allowable.

Specified in the explanation of Article 10 paragraph (1) UUHT, namely the Agreement Raises Debt Relationships can be prepared by Deeds Under Hands or to be made by deed Authentic, depending on the Provisions Governing Law The agreement material. This means that between the Two Debt must be made in writing, not necessarily with the Deed of Authentic or deed notarial, could be created in the Lower Hand, provided it is done pursuant to Rule Governing Law Matter The deal, All Matter The terms are not required Poured the Authentic Deeds, the material Agreement Raises Debt Relationships can be poured or made by deed in the Lower Hand. ${ }^{4}$ In fact, the credit ceiling of Rp. 50,000,000. (Fifty million Rupiah) Credit Agreement made in the form of Deeds in Hands Down only. That view may be justified in Banking Practice, considering there is no provision which requires that legislation made by the Deed of Credit Agreement Authentic. Based on interview with a notary / PPAT in District of Semarang, Nicky Santika, Credit agreements can be made either by Deed or Deed Hands Down. Practices that apply to credits for the large amounts usually made with the Credit Agreement Deed. As for credits which are small, reasonably made by the Deed in the Lower Hand.

Under the terms of Article 10 paragraph (3) UUHT, possible Granting Mortgage on Land Rights Conversion Rights are derived from the Old that already meet the requirements for Registered, but unfinished Registered. So, Customary Rights lands that have been converted into Land Rights under the Basic Agrarian Law, while The administration process is not yet completed, it can be possible to be used as Collateral

\footnotetext{
${ }^{4}$ J. Satrio, 2002, Hukum Jaminan, Hak Jaminan Kebendaan, Hak Tanggungan, Book 2, First Edition, PTCitra Aditya Bakti, Bandung, p. 272.
} 
Mortgage Debt burdened. Of provisions in the Explanation on Article 10 paragraph (3) UUHT known, that the administration of Encumbrance of the soils Rights of Indigenous derived from the conversion that has met the requirements for registration can be done as long as "simultaneously" with the Application for Registration of Rights to the Land Office land.

This means Granting Mortgage and Deed Making the imposition of Encumbrance (APHT) can be done in the state of land used as places yet Certified Mortgage. Land Registration Application was filed in conjunction with the Application for Registration of Mortgage concerned. Thus the manufacture APHT not need to wait until the Land Rights that serve Certified Warranty on Name of Mortgage.

\subsection{Barriers Which Appears In Loading Liability Rights Process On Land The Which Hasn't Registered In District of Semarang}

Based on interview with a notary / PPAT in District of Semarang, Nicky Santika, any Conditions Make Barriers appear on Encumbrances on Land hasn't registered in the District of Semarang else that is Giver Mortgage on land that has not been certified the death and have Heirs while receivables creditors unpaid. In practice, in the face of the problem of unpaid loans with collateral land that has not been certified, while the Debtor has died and left Heirs. It is problem because Registered given before Land Collateral Mortgage so when Giver, there any difficulties to transfer Land which hasn't registered for heirs.

Another problem is When Writing Error Occurred existence. In Making a Writing Error Deed It is very fair and very often happen. Except both problem, in this case the Relevant never encountered problematic, namely when Installation Mortgage Ranked Second. At the time of going to do Installation Mortgage Ranked second, the Land Deed Official (PPAT) Ever Meet the Graffiti on the Certificate of Land already given their Mortgage Notes First Rank.

\subsection{The Solution On Process Appear In Loading Liability Rights In The Land That Hasn't Registered In District Of Semarang}

Solutions to overcome barriers that comes in the Imposition Process Mortgage on land that has not been registered in the District of Semarang to problems in the previous point can be seen in the following description;

- According to researchers, the Bank still can Using their Right to Install Based on the SKMHT or APHT if Certificates The ground has been completed, according UUHT Given SKMHT Special Characteristically and it can be said It is a Power of Absolute, which not also be ended with the death of Kuasa.Berhubung UUHT Giver has Assigning SKMHT An Absolute Power of Attorney, then on this subject no longer contracted or included in SKMHT.

- To Overcome The problematic of the Land Deed Official (PPAT) should Undertake Renvoi or correction on the left Deed wrong article. Renvoi or correction can be legalized if Graffiti with replacement word or phrase One of Writing, Addition passed word or phrase if there are missing or have not been written, and Graffiti without Replacement validated when there is a word or phrase that is repeated. Where under the Sentence Correction or Renvoi Must be signed or initialed by the Parties that the Giver and Encumbrance Holder, witnesses and Land Deed Official (PPAT).

- To cope with the problematic of the Land Deed Official (PPAT) should perform checks on the Certificate of Land Rights in the National Land Agency (BPN), and the National Land Agency (BPN) to replace it with a Certificate of Land Rights a new 
one. If the Debt Secured by Mortgage Ranked First have Paid, the National Land Agency (BPN) will do the Roya and the Certificate of Land which only later was installed Mortgage First Rank. Whereas if the Debt Secured by Mortgage rating yet Paid First, the National Land Agency (BPN) will replace it with a Certificate of Land New and do Installation Mortgage Ranked Second.

\section{Closing}

\subsection{Conclusions}

- Imposition implementation of the Land Mortgage Certified yet in practice never done Bank to make APHT Directly on the lands that have not Certified. Bank in this case was limited to making SKMHT only. Legal considerations are not made APHT to lands that have not registered because there is a possibility of Rights over the Land Ownership Unclear. In practice Notary / PPAT always made a Power of Attorney Gives Mortgage (SKMHT) in accordance with Article 15 (4) UUHT, to Bind Guarantee on lands that have not been Certified which will be used as collateral.

- Emerging Barriers in the Process of Mortgage Encumbrances on land that has not been Registered in District of Semarang are as follows:

- When Giver Mortgage on the land that has not been certified and Has Died Heirs while creditors unpaid receivables.

- Another obstacle is when happened on Writing Error. In Making a Writing Error Deed It is Very Reasonable and often once occurred.

- Another problem is when Installation Mortgage Ranked Second, the Land Deed Official (PPAT) Ever Meet the Graffiti on the Certificate of Land already given their record Mortgage First Rank.

- Solutions in Emerging Overcoming Obstacles in the Process of Mortgage Encumbrances on land that has not been Registered in District of Semarang

- Credit has been due, then Credit Cover by Credit Insurance. If credit has been falling Tempo and Credit Insurance has Expired, it will be billed until Paid to his heir by doing approach Kinship with the Offering Relief Lending, Heirs of the Relevant Request for Conducting Sales under the hand on the Security Object.

- Land Deed Official (PPAT) should Undertake Renvoi or correction on the left Deed paper is wrong. Renvoi or correction can be passed Graffiti with replacement if either writing words or sentences, Addition passed if there are words or phrases missing or has not been written, and Graffiti without Replacement validated when there is a word or phrase that is repeated.

- Land Deed Official (PPAT) must Conducting Checking on Certificates of Land Rights in the National Land Agency (BPN), then the National Land Agency (BPN) Replace it with the Certificate of Land new. If the Debt Secured by Mortgage Ranked First has paid off, the National Land Agency (BPN) will do the Roya and the Certificate of Land which only later was installed Mortgage First Rank.

\subsection{Suggestions}

- That in order for implementation of Encumbrances can walk smoothly, then the Parties that the Borrower as the Giver Mortgage and Mortgage Lenders as the Holder must immediately Completing the requirements needed in the implementation of Encumbrances Land.

- To Ensure Legal Certainty and legal protection should the Bank Avoiding to Receive collateral in the form of Land Used Hak Adat are not yet certified, although UUHT 
have Gives possibility to it, Recalling when Binding Credit has been carried out and then the day turns Land Certificate can not be issued, the creditor in a weak position because it is not the creditor have Rights under Preferred Mortgage, therefore to make the registration of the object Encumbrance Encumbrance Certificate must have had, while Making SKMHT will find Constraints When Associated with Length of Land Registration process.

- In the future highly expected that the Government through the National Land Agency to Organizing the process of certification of the country in a relatively short time so as to Support the Society of Economic Activity.

\section{Bibliography}

[1] Kantor Bank Indonesia Semarang, 2018, Penanganan Kredit Bermasalah, Bank Indonesia, Semarang.

[2] Satrio, J. 2002, Hukum Jaminan, Hak Jaminan Kebendaan, Hak Tanggungan, Buku 2, First Edition, PT. Citra Aditya Bakti, Bandung

\section{Legislation:}

[1] Constitution of the Republic of Indonesia 1945 of Law 5 of 1960 on Basic Land Principles (BAL).

[2] Act 4 of 1996 on Loading Liability Rightsatas of Land (UUHT)

[3] Government Regulation No. 24 of 1997 on Land registration

[4] President Regulation No. 17 of 2015 concerning the Ministry of Agricultural and Spatial Planning

[5] President Regulation No.20 of 2015 concerning the National Land Agency;

[6] President Instruction of Indonesian Republic No. 2 of 2018 on PTSL in the whole territory of the Republic of Indonesia.

[7] Minister of State for Agrarian Affairs / Head of National Land Agency (PMNA / KBPN) No. 5 of 1996 on Registration of Loading Liability Rights.

[8] Minister of State for Agrarian Affairs / Head of National Land Agency Number 3, 1997 on Application government regulation No. 24 of 1997 on Land Registration;

[9] Minister of State for Agrarian Affairs / Head of National Land Agency Number 12 of 2017 Land on PTSL.

[10] Manual applying of Government Regulation No.1069/3.1-100/IV/2018 on PTSL of 2018. 